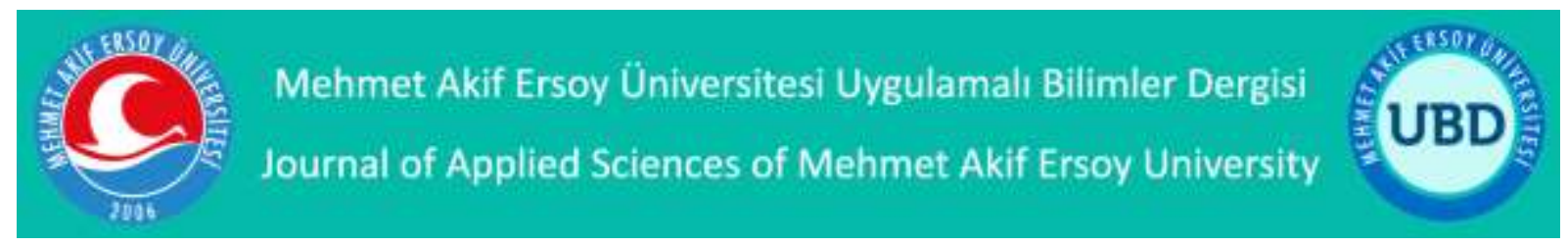

\title{
Modern Elektronik Laboratuvarları İçin Otomasyon Sistemi ve Yazılımının Geliştirilmesi
}

\author{
Fatih YOLDAŞ ${ }^{1 *(D)}$, Ramazan ŞENOL ${ }^{2}$ \\ ${ }^{1}$ Lecturer, Burdur Mehmet Akif Ersoy University, Bucak Emin Gülmez Technical Sciences Vocational School, \\ Department of Electricity and Energy, Burdur, Turkey \\ ${ }^{2}$ Assoc. Prof. Dr., Isparta Applied Sciences University, Faculty of Technology, Electrical-Electronics \\ Engineering, Isparta, Turkey
}

Geliş Tarihi/Received: 24.08.2020

Kabul Tarihi/Accepted: 23.03.2021
Doi: $10.31200 /$ makuubd. 784806

Araştırma Makalesi/Research Article

\section{ÖZET}

Bu çalışmada, mühendislik fakülteleri ve meslek yüksekokullarının ilgili bölümlerinde bulunan elektronik laboratuvarlarının kontrolü ve takibini sağlamak üzere, mikrodenetleyici ile kontrol ve kumanda işlevini uzaktan yapabilen bir otomasyon sistemi tasarlanmış ve gerçekleştirilmiştir. Arayüz ve kart okuma sistemi ile öğrenci bilgi veritabanı üzerinde oluşturabilmekte ve geliştirilen algoritma ile öğrenci sadece sorumlu olduğu derslere dair deney setlerine erişim sağlamaktadır. Hazırlanan program ve algoritma öğrencilerin yoklama listesini arşivleyebilmekte ve geçmişe yönelik öğrencilerin çalışma süreçlerini takip etme imkânı sunmaktadır. Geliştirilen iki aşamalı kart okuma sistemi arıza takibi, kimlik yönetimi ve laboratuvar ekipmanı denetimini sağlayabilmektedir. Bu çalışma ile öğrencilerin uygulama derslerinde laboratuvarı daha verimli kullanması amaçlanmıştır. Öğrenciler ile uygulamalı olarak yapılan 13 Haftalık süreç takibi ile otomasyon sisteminin önceki yıllar ile verim karşılaştırılması yapılmıştır.

Anahtar kelimeler: Mikrodenetleyici, Laboratuvar, RFID.

\footnotetext{
* Sorumlu yazar/Corresponding author

E-mail/e-ileti: fyoldas@mehmetakif.edu.tr
} 


\title{
Development of Automation System and Software for Modern Electronics Laboratories
}

\begin{abstract}
In this study, an automation system that can remotely perform control and control functions with a microcontroller has been designed and implemented in order to control and monitor the electronic laboratories in the relevant departments of engineering faculties and vocational schools. Within the scope of this study, an automation system that can remotely control and command functions with a microcontroller was designed and implemented in order to control and monitor the electronics laboratories in the relevant departments of engineering faculties, technology faculties and vocational schools. With the interface and card reading system, the student can create on the information database and with the algorithm developed, the student can only access the experiment sets for the courses he is responsible for. The prepared program and algorithm can archive the attendance list of the students and provide the opportunity to follow the working processes of the students in the past. The two-stage card reading system developed can provide fault tracking, identity management and laboratory equipment control. With this study, it is aimed for students to use the laboratory more efficiently in practice lessons. The efficiency of the automation system was compared with the previous years with the 13week process follow-up applied with the students.
\end{abstract}

Keywords: Microcontroller, Laboratory, RFID.

\section{GİRIŞ}

Mühendislik eğitiminde ana unsur, teori ve pratiğin uyumudur, bu da uygulama ile mümkündür. Öğrencinin eğitim aldığ1 alanda gördüğü uygulama, öğrencinin başarısını doğrudan etkilemektedir. Mühendislik alanındaki alınan teorik eğitim öğrencinin uygulama ile buluşamaması durumunda kalıcılığını ve idrak edilebilmesini sağlayamamaktadır. Bu nedenle her teorik mühendislik eğitimi uygulama ile paralel gitmelidir ki, öğrenciye aktarılan bilgi kalıcı olabilsin.

Geliştirilmiş olan yazılım ve donanım ile ilgili derslere ait uygulama laboratuvarları bir otomasyon sistemine kavuşmaktadır. Geliştirilen yazılım öğrencilerin üniversite kimlik kartları ile uyumlu bir şekilde çalışmakta olup RFID teknolojisi ile ders yoklaması ve kullanılan laboratuvar cihazlarının takibini yapmaktadır. Laboratuvar ortamında yapılan uygulamalar ile oluşan öğrenci verileri, yine bu çalışma kapsamında oluşturulan bir veri tabanına arşivlenmekte 
ve geçmişe dönük performans izlemesini ve cihazların arıza takibinin güncel olarak yapılabilmesi sağlanmaktadır. Öğrencilerin dönem boyunca yoklama takibi yapılabilmektedir. Öğrencilerin uygulama derslerinde deney setleri ile geçirdikleri süreler izlenebilmektedir. Deney setlerinin sadece gerekli olmaları durumunda kullanılmaları sağlanmaktadır. Gereksiz yere laboratuvar ekipmanlarının kullanımı ve arıza yapmaları minimuma indirilmektedir. Geçmişe dönük olarak arşivlenen veriler, laboratuvar cihazlarının uzun ömürlü ve daha verimli kullanımını sağlamaktadır. Ayrıca tüm laboratuvar işleyişinin tarih, saat ve kullanıcı bilgileri ile kayıt altına alınması laboratuvar uygulamalarında verimi artırmaktadır.

Medin ve Petric (2015) çalışmalarında elektroniğin ilkelerinden bahsederken elektronik laboratuvarının tasarımı ve inşaasını tanımlamış, böylelikle mikrodenetleyiciler hakkında bilgi sahibi olmalarını amaçlamıştır. Gömülü sistemlerin tasarım ve mimarisinin bir laboratuvar ortamında laboratuvar tasarımı için fizik dersinde temel ölçümlerin öğretilmesinde yeni bir yaklaşım sunulduğunu belirtmişlerdir. Geliştirilen deney seti ile HD44780 ile uyumlu bir LCD modülü kullanma, ultrasoniksensörler ve ölçüm mesafesi uygulamalarını gerçekleştirmişlerdir. Laboratuvarların ve gömülü sistemlerin etkileşiminin öğrenciler üzerinde güçlü bir etkisi olduğu tespit etmişlerdir. Geleneksel öğretim yöntemi kullanıldığında, öğrencilerin bir sorunun çözümüne doğru yoğun bir şekilde çalışmak için motivasyon eksikliği sergiledikleri ve sıklıkla yanlış anlamalarla uğraştıklarını, diğer yandan derslerin laboratuvara taşınması, elektronik devrelerin ve bilimsel kavramların anlaşılmasında belirgin bir iyileşmeye neden olduğunu vurgulamışlardır.

Soriano vd. (2015) çalışmalarında, genç mühendislik öğrencilerine otomatik kontrol giriş derslerine giderek daha fazla yer verildiğini belirterek, öğrencilerin sınıfta incelenen teorik kavramları deneyimlemeleri ve motivasyonlarını arttırmak için laboratuvar çalışmalarına uygun bir platformun bulunmasının kritik bir karar haline geldiğine değinmişlerdir. Yakın zamana kadar yalnızca kapalı platfomların kullanıldı̆̆ı, ancak günümüzde pek çok açık kaynaklı donanımların bulunduğunu vurgulamışlardır. Çalışmalarında otomatik kontrol giriş dersleri için çok disiplinli, düşük maliyetli bir açık platform sağlamak için, robotik bir kol manipülatörü ile farklı bir mobil robot tarafından kolayca programlanabilen açık kaynak eğitim platformunun bir örneğini sunmuşlardır.

Merino vd. (2016) Yaptıkları çalışmada, öğrencilere robotik alanında eğitim almalarını sağlayacak bir tasarım geliştirdiler, çalışmalarında belirtildiği üzere tasarlanan cihaz STEM (Science, Technology, Engineering, Matehematics) alanında öğrenciyi uygulamalı olarak 
geliştirmeyi hedeflemektedir. Hazırlanan deney setinde Atmega mikrodenetleyiciye sahip Arduino geliştirme kartı kullanılmıştır. Bu deney setinin amacı öğrenci motivasyonunu düşük maliyetli bir deney seti ile geliştirmek olarak açıklanmıştır.

Sarıkaş ve Yayla (2017), Arduino UNO kullanarak Labview ile programlanabilen bir deney seti geliştirmiştir. Öğrenci hazırlanan arayüz ile geliştirilen mikrodenetleyici deney setinde deneyini yapabilir ve sonuçların takip edebilmektedir.

Hudayberdiev'in 13. Uluslararas1 Intelligent Systems Sempozyumunda, (INTELS'18)'de sunmuş olduğu "Algorithm for the Development of a Training Set that Best Describes the Objects of Recognition" başlıklı makalede laboratuvar cihazlarının akıllı hale getirilmesi için algoritma yöntemleri seçiminden bahsetmiş̧tir.

Gülcan (2019) çalışmasında uzaktan kontrollü arm tabanlı mikro denetleyici deney seti tasarımı ve gerçekleştirilmesini yapmıştır. Tasarlanan web sayfasına bir randevu sistemi kurularak hangi kullanıcıya ve ne zaman hizmet verileceği daha önceden kayıt altına alınabilir. $\mathrm{Bu}$ tür ek özellikler ile geliştirilecek bir sistem sayesinde kullanıcıların daha kaliteli ve esnek imkânlara sahip deneyleri gerçekleştirme imkânı olacaktır. Bu deney setinde LCD'nin yetersiz olduğu daha büyük ekran gerektiği, Sisteme müdahale edebilme şansının az olması, Sistemde meydana gelen arızaların sistem tarafından kayda alınması gerektiği yine tez sahibi tarafindan tez içerisinde dile getirilmiştir.

Arduino' nun sahip olduğu geliştirme ortamının kullanımı ve anlaşılması kolay olduğu için mühendislik uygulamaların yanında eğitimde de kullanımı oldukça yaygınlaşmaya başlamıştır. Bu çalışma kapsamında geliştirilen laboratuvar otomasyonunun; uygulamalı elektronik derslerinin işleyişinde sürecin takibini kolaylaştırmasının yanında, ilgili bölümlerde eğitim gören öğrencilere; Internet of Things (IoT) ve endüstri 4.0 için bir yol gösterici olması da hedeflenmektedir.

\subsection{Kontrol Laboratuvarı Otomasyonu}

$\mathrm{Bu}$ çalışmanın konusu olan Laboratuvar kontrolü ve değerlendirme otomasyonu algoritmaları Microsoft Visual Studio 2010, Visual C\# uygulama oluşturma- geliştirme ortamında yazılarak derlenmiş ve test edilmiştir. Görüntü işleme konusunda $\mathrm{C}$ programlama dili kendini kanıtlamıştır. Günümüzde gerçekleştirilen birçok akademik ve ticari çalışma $\mathrm{C}$ programlama dilinde geliştirilmiştir. Günümüzde C programlama dilinin farklı sürüm ve 
geliştirilmiş türleri bulunmaktadır. Bu çalışmayı gerçekleştirmek için geliştirilen yazılım algoritmaları Microsoft Visual Studio 2010 C\# uygulamasında çalıştırılarak test edilmiştir.

Birçok uygulamada aktif kullanılan Open CV Kütüphanesi ve örnekleri bu çalışmaya başlangıçta 1şık tutmuştur. Open Cv kütüphanesi Intel firması tarafından açık kaynak kod ile C dili temel alınarak geliştirilmiş performansı yüksek bir kütüphanedir. Open Cv Kütüphanesi C\# dili ile doğrudan çalışamaz. Çünkü Open Cv kütüphanesi C dili için geliştirilmiş ve yazılım kaynakları C dili ile oluşturulmuştur. Bu nedenle ara yüz olarak ya da sarmal diye nitelendirilen ve bu gibi uygulamaların daha özel uygulamalar ile kullanılmasına olanak tanıyan EmguCv Kütüphanesi çalışmada kullanılmıştır. EmguCv kütüphanesi Open Cv'nin tüm fonksiyon ve alt uygulamalarını bünyesine taşımıştır. Ayrıca çapraz platform ve .Net Framework sınıf yapısına uygun geliştirilmiştir. Dolayısıyla C\# dili ile kullanılabilmesi ve açık kaynak kod mantığı ile oluşturulmuş olması uygulamamızda görüntü işleme kütüphanesi olarak yer bulmasını sağlamıştır.

\subsection{Mühendislik Eğitimi ve Laboratuvar Çalışmalarının Önemi}

Günümüzün mühendislik eğitiminde teknolojik materyallere olan ihtiyaç geçtiğimiz yıllara göre çok daha fazladır (Çepni ve Özmen, 2010). Bugünün mühendislik fakültesi öğrencisi, yarının mühendisleri ve akademisyenleri olacak kişiler modern ve güncel materyaller ile eğitim almalı, yenilikler yakından takip edilmelidir.

Uygulamalı eğitimin yapılabilmesi laboratuvarlar ile mümkün olup, laboratuvarlar da belirli düzen ve yeterli sayıda deney seti ile donatılmalıdır. Yeterli sayıda deney setinin laboratuvarlarda bulunmaması durumunda, akademisyen gösteri deneyi yapmak durumundadır. Ancak gösteri deneyi kalabalık öğrenci topluluğu ile yapıldığında tam anlamıla konunun aktarımını sağlayamamaktadır. Öğrencilerde ilgisizliğe yol da açmaktadır (Gürdal, 1991; Temiz ve Kanl1, 2005).

Mühendislik eğitimi alan öğrencinin verimli uygulama eğitimleri alabilmesi yeterli deney seti ve donanım ile mümkündür, maalesef deney setleri ve donanımların temini ise geniş bütçeler ile mümkündür. Çalışmanın ilk aşamasında kontrol laboratuvarları için bir deney seti tasarlanmış olup, ikinci aşamasında kontrol laboratuvarları için denetim otomasyonu geliştirilmiştir. Çalışmada, ucuz ve kolay ulaşılabilir bir mikrodenetleyici olan STM32F4 Discovery geliştirme kartı ve Atmega 2560 mikrodenetleyicisinden yararlanmak için Arduino Mega 2560 geliştirme kartı kullanılmıştır. 


\section{MATERYAL VE METOD}

\subsection{Laboratuvar Otomasyon Sisteminin Tasarımı ve Uygulaması}

Bu çalışma kapsamında geliştirilen ikinci donanım olan laboratuvar otomasyon sistemi, laboratuvar uygulamaları için bir düzen içerisinde uygulamaların yapılmasını sağlamaktadır. Geliştirilen bilgisayar yazılımı ile uygulama ve ders süreçleri kayıt altına alınmaktadır. Geliştirilen bu yazılıma adapte edilen kart okuma ve deney setleri kontrol sistemi ise sistemin donanımsal alt yapısını oluşturmaktadır. Böylelikle laboratuvar uygulamalarında öğrenci tüm işlemlerinde kendi öğrenci kimlik kartından yararlanacaktır. Oluşturulan yazılım, öğrencinin yoklamasını alacak ve sorumlu olduğu dersler için deney setlerini kullanımına izin verecektir. Oluşturulan veri tabanı, öğrenci yoklamasını ve deney setleri kullanım geçmişini arşivleyecektir.

Tasarlanan sistem; kişilere bağlı bir laboratuvar denetiminden elektronik ve yazılımsal bir denetime geçiş sağladığ 1 için, Internet of Things (IoT) için bu alanda çalışan öğrencilere yol gösterici olacaktır. Ayrıca deney, geçmiş çalışmalarının arşivlenmesi, daha uzun ömürlü deney seti kullanımı ve arızalar için erken müdahale imkânı sağlayacaktır. Bu bölümde hazırlanan laboratuvar otomasyon sisteminin yazılım ve donanım kısımları ayrı ayrı incelenecektir.

\subsection{Algoritma}

Laboratuvar takibi ve izlemesini gerçekleştiren program çok yönlü bir algoritma ile oluşturulmuş olup sistemin donanımı ve veri tabanı ile uyum ile çalışmaktadır. Şekil 1'de laboratuvar takip otomasyon sisteminin ana ekran ara yüzü görülmektedir. Ana ekran üst sekmesinde yer alan menü bileşenleri ile sistem görevini yerine getirmesi sağlanmaktadır. Üst sekmede yer alan “ders ekranı”, "Yoklama arşivi”, "Uygulama arşivi”, "Laboratuvar düzeni”, "Öğrenci kayıt" bölümlerine ait çalışma algoritmaları aşağıda verilmiş ve detaylı bir biçimde açıklanmıştır. 


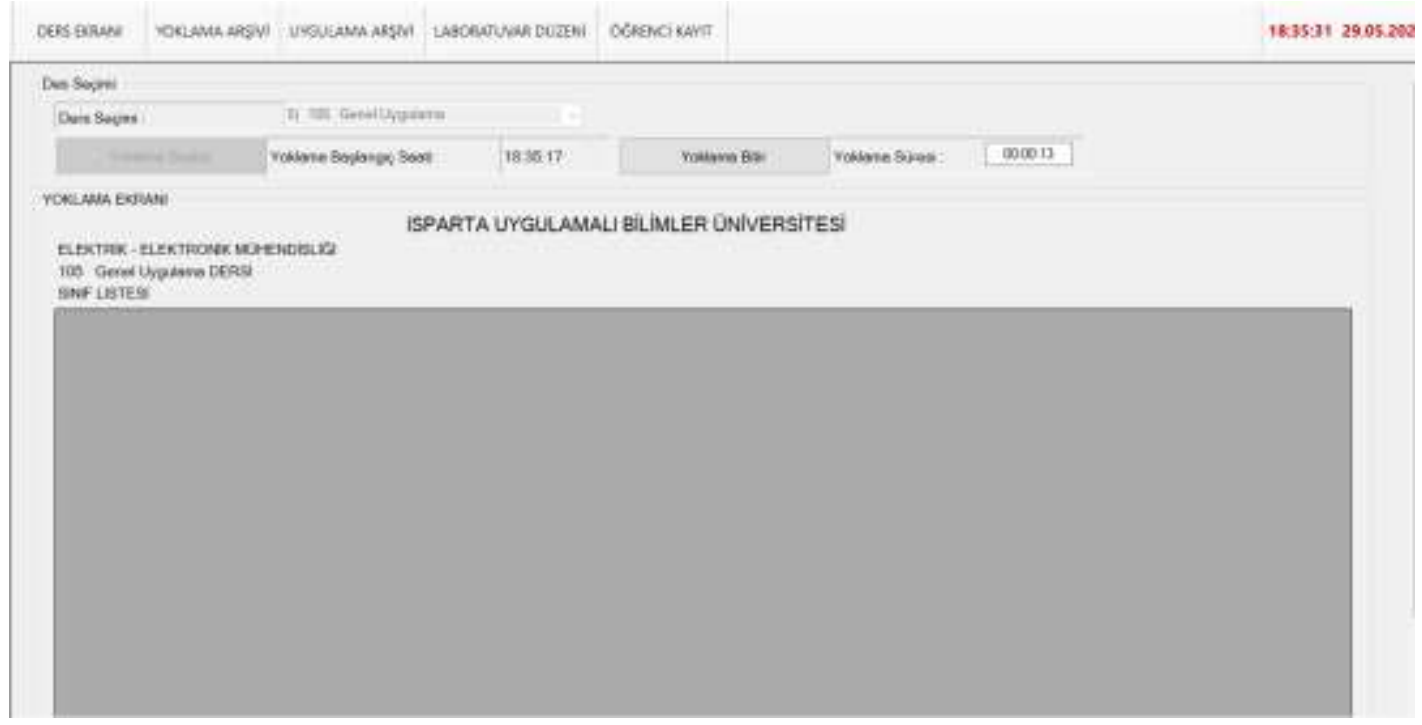

Şekil 1. Laboratuvar otomasyonu ana ekranı

Sistem, laboratuvarı kullanan yönetici ve öğrenci için farklı algoritmaları takip etmektedir. Laboratuvar yöneticisi yapmak istediği çalışmaya göre, bu çalışma kapsamında hazırlanmış olan program üzerinden bir ders seçmesi ile laboratuvar kapısına montajı yapılan RFID kart okuyucu enerjilenir. Yöneticinin bu işlemi yapması, ders yoklamasını başlatmaktadır. Veri tabanına daha önceden kayıtlı tüm öğrenciler kapı girişinde giriş saati ile birlikte yoklamaya dâhil olur. Yöneticinin seçtiği ders kapsamında program tarafından hazırlanan yoklama listesi veri tabanına otomatik olarak kaydedilmektedir. Bu süreci gösterir algoritma Şekil 2'de verilmiştir. 

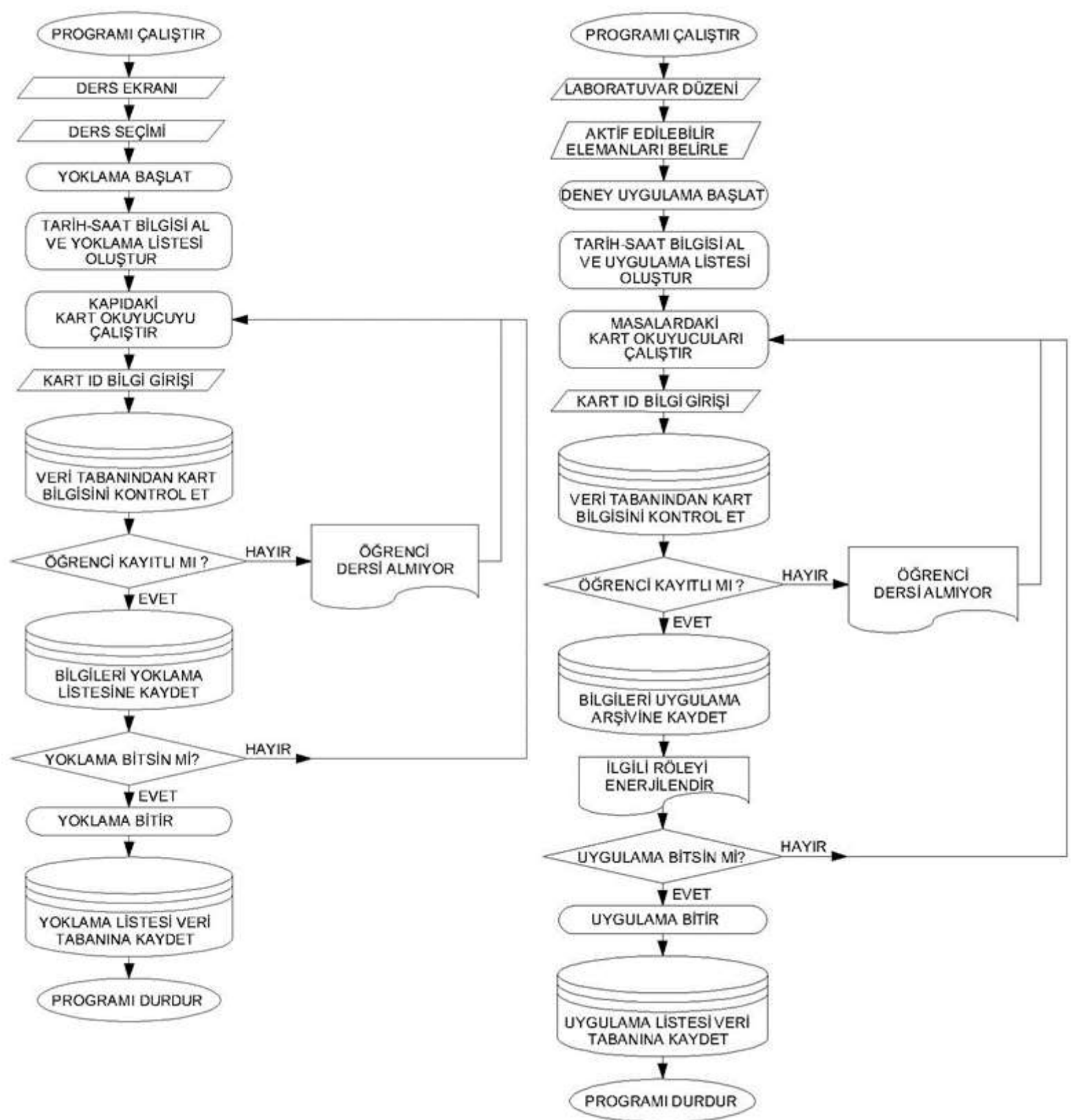

Şekil 2. Ders ve laboratuvar düzeni ekranı algoritmik gösterimi

Bu çalışma kapsamında hazırlanan sistem, yukarıda bahsedilen ve Şekil 2'de gösterilen yoklama takibi dışında, öğrencilere yönelik deney setlerinin de takibini yapmaktadır. Kapıda bulunan kart okuyucu ile yoklamaya dâhil olan öğrenci, masalarda bulunan kart okuyucular ile deney setlerinin enerjilenmesini sağlayabilmektedir. Ancak deney setlerinin kontrolü ve enerjilenmesi için öncelik yönetici bilgisayardan verilen yetki ile sağlanmaktadır. Öğrenci masada bulunan kart okuyucuya öğrenci kimlik kartını okutması ile sistem veri tabanından öğrencinin aldığı dersleri kontrol etmektedir. Öğrencinin almadığı bir derse dair deney setinin enerjilenmesi yönetici izin vermediği sürece mümkün olmamaktadır. Öğrencinin deney seti ile 
çalışma süresinin kaydı, yoklama listesi haricinde bir liste ile ayrıca veri tabanına arşivlenmektedir.

Şekil 2'de görülen algoritmalar sistem işleyişine dair bilgi vermektedir. Bu algoritmalar haricinde sistem, yönetici için veri tabanında arşivlenen geçmiş tarihli dökümanlara da erişim sağlamaktadır. Bu çalışma kapsamında hazırlanan programın ilgili sekmeleri ile geçmiş tarihli verilere, veri tabanından ulaşımı sağlayan algoritma Şekil 3 'te görülmektedir.

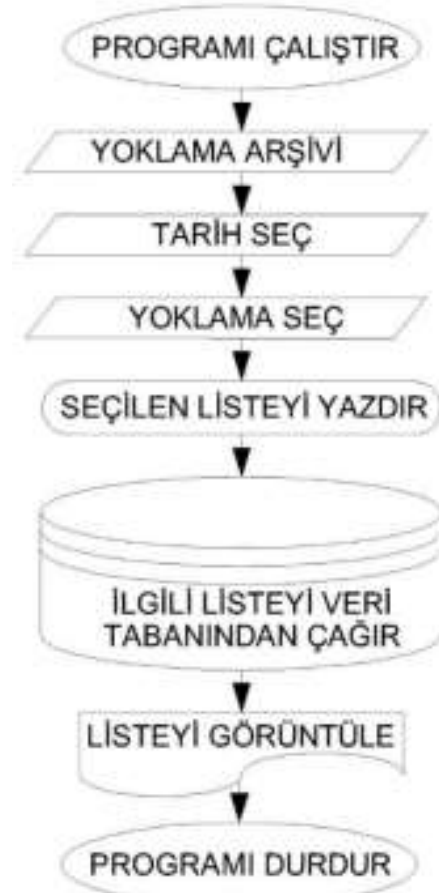

Şekil 3. Yoklama ve uygulama arşivi erişimi genel algoritması

\subsection{Sistemin Donanımsal Alt Yapısı}

Sistem donanımını, laboratuvar içerisinde bulunduğu konuma göre gruplandırılacak olursa, üç bölümde incelenmesi gerekmektedir. Şekil 2 ve Şekil 3 'de görüldüğü üzere, ilk bölüm olarak laboratuvar kapısında öğrenci kimlik kartları ile uyumlu, 13,56 MHz frekans ile haberleşen bir RFID kart okuyucu bulunmaktadır. Bu kart okuyucu ile sınıf yoklaması her öğrenci için kapıda öğrenci kimlik kartları ile alınmaktadır. İkinci kısım sistem yazılımının yüklenmiş olduğu ve veri tabanının bulunduğu yönetici bilgisayar ve üçüncü kısmın kontrolünü sağlayan arduino mikrodenetleyici kartıdır. Üçüncü kısım deney setlerinin bulunduğu masalar için geliştirilen, masaların her birinde bulunan RFID kart okuyucu ve röle takımlarıdır. 


\section{BULGULAR}

\subsection{Sistemin Kullandığı Veri Tabanı}

Sistem için veri tabanı olarak Microsoft Access'ten faydalanılmıştır. Laboratuvarı kullanacak olan öğrencilerin aldığı dersler ve öğrenci kimlik kartlarına dair bilgiler bu veri tabanına arşivlenmektedir. Ayrıca veri tabanına öğrenci bilgileri haricinde laboratuvarda uygulama yapılabilecek dersler de eklenip değiştirilebilmektedir.

Dönem boyunca laboratuvarda işlenecek derslerin yoklama kayıtları ve deney yapan öğrencilerin bilgileri de hazırlanan program ile bu veri tabanına kaydedilmektedir. Hazırlanan program ile dönem başında öğrenci veri tabanına eklenmektedir. Veri tabanı içerisinde öğrenci numarası, isim, soy isim, bölümü kaydedilmektedir. Okula başlayan öğrencinin kaydının bir kere alınması, öğrenci okulu bitirinceye kadar arşivlenmesi için yeterli olacaktır. Öğrenci kimlik kartını kaybederse, yeni kimlik kartı ile sistemden küçük bir revizyon ile yeni kart sisteme adapte edilebilecektir.

Veri tabanında öğrenci kaydı tutulmaktadır. Laboratuvar uygulaması yapılabilecek 4 ders öngörülmüştür, bu nedenle sadece bu dersler için 0 ile 16 sayıları arasında binary kodlama mantığı ile dersler kodlanmıştır. Ders kodlarına ait detaylara program ile ilgili kısımda detaylı değinilecektir.

Laboratuvarda işlenen her ders ve derse katılan öğrencinin bilgisi veri tabanına yoklama listesi olarak kaydedilmektedir. Kaydedilen yoklama listesi dersin işlendiği tarihi ve öğrencilerin her birinin derse giriş saatini kayıtlı bulundurmaktadır.

Program kısmından bu arşive erişim sağlanmakta ve Şekil 4'da görüldüğü gibi geçmiş tarihli yoklama verileri görülebilmektedir. 


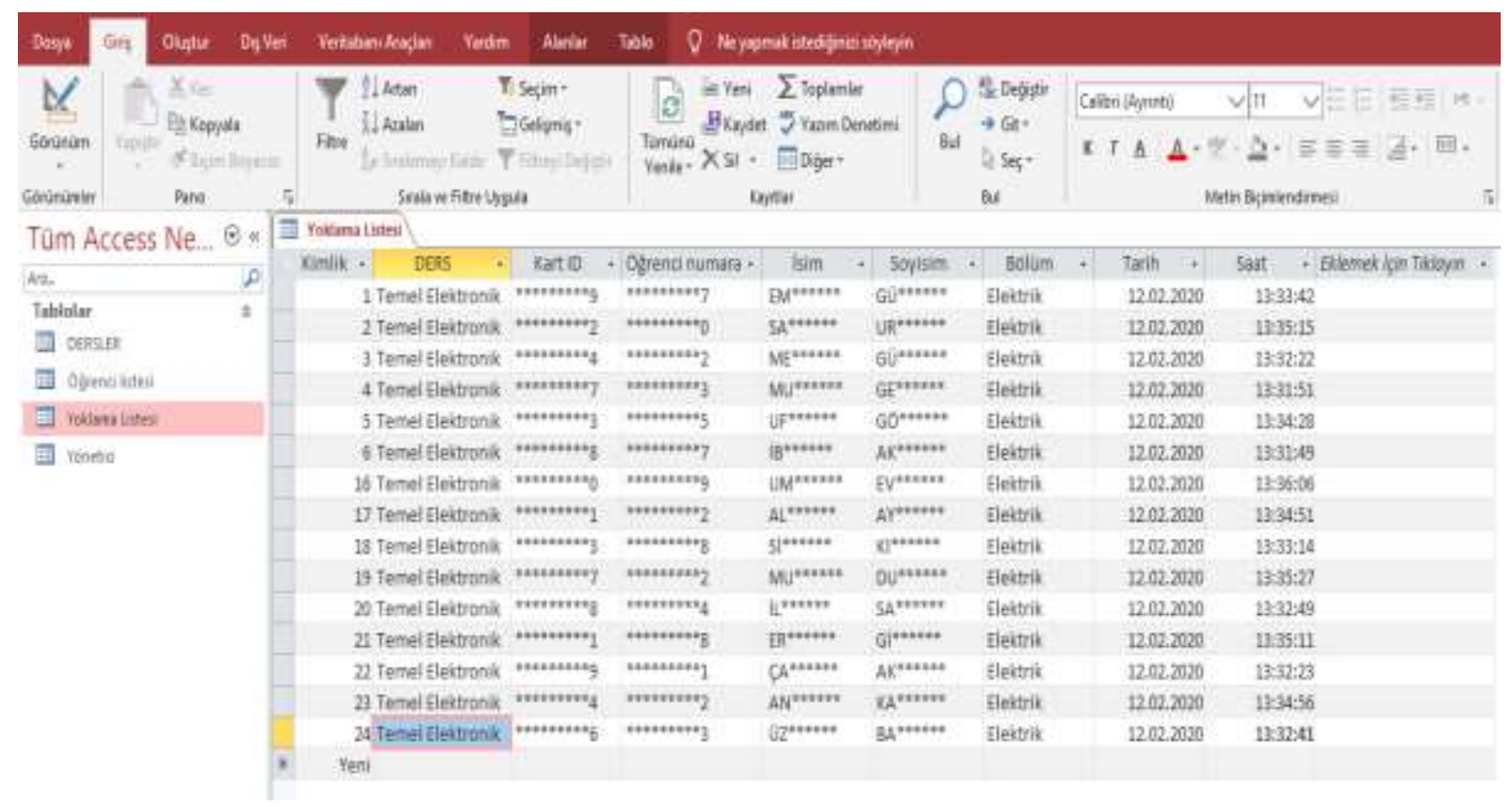

Şekil 4. Veri tabanına kaydedilen yoklama listeleri

Laboratuvar otomasyon sisteminin kullanımı ve işletmesi tek bir akademisyen tarafından sağlanmayacak, farklı ders ve laboratuvar uygulamalarının farklı akademisyenler tarafindan yönetileceği öngörüldüğü için, sistem girişi için farklı kullanıcı adları ve şifreler belirlenebilmektedir. Sistem veri tabanı yoklama listeleri ve kullanım geçmişini arşivlediği için bir güvenlik önlemi alınma gereği duyulmuştur.

\subsection{Sistemin Yazılımı ve İşleyişi}

Laboratuvar otomasyonu için tasarlanan program 5 ana menüden oluşmaktadır. Ekran görüntüsünün verilmiş olduğu Şekil 5 'de 5 ana menü görülmektedir. Bu menüler sırasıyla; Ders Ekranı, yoklama arşivi, uygulama arşivi, laboratuvar düzeni, öğrenci kayıt menüleridir.

Ders ekranı menüsü, laboratuvar uygulama dersi süresince öğrencilerin ders yoklamaları anlık olarak bu menüde listelenmektedir. Ders yöneticisi yoklamayı başlatmak için bir ders seçip "yoklama başlat” butonuna basarak yoklamayı başlatabilmektedir. Bu süreç aynı zamanda tarih ve saat bilgilerini de otomatik olarak kaydederek arşive tüm öğrencilerin derse giriş zamanlarını da ileri tarihlerde inceleyebilmeyi sağlamaktadır.

Geçmiş tarihli yoklama listeleri incelenmek istendiğinde, bu çalışma kapsamında hazırlanan programın ana menüsünden yoklama arşivi bölümü seçilmektedir. Yoklama arşivi menüsünde tarih ve dersler seçilerek veri tabanından istenen dersin yoklama listesine 


\section{Yoldaş, F. \& Şenol, R.}

ulaşılabilmektedir. Ayrıca "seçilen listeyi yazdır" butonu ile de arşivden bir yoklama listesinin çıktısı alınabilmektedir.

Laboratuvar yoklamaları kapıda bulunan kart okuyucu ile alınmakta, ancak laboratuvar deney setlerinin kullanımı her masada bulunan ikinci bir kart okuyucu ile yapılmaktadır. Masada bulunan kart okuyucu, bu çalışma kapsamında hazırlanmış olan programın "laboratuvar düzeni” sekmesinden aktif edilmektedir. Laboratuvar düzeni sekmesinde, öğrencilerin hangi deney setlerini kullanabileceği yönetici tarafından seçilebilmektedir. $\mathrm{Bu}$ seçimi ister yönetici yapabilmekte, isterse öğrencinin aldığı derse göre sistemin veri tabanından kontrol ederek yapabilmesini sağlamaktadır. Bu seçimin yapılması ile uygulama başlat butonu, masalardaki kart okuyucuların aktif olmasını sağlamaktadır. Hangi masada hangi öğrencinin çalışma yaptığ 1 da bu sekmedeki ara yüz ile görüntülenerek veri tabanına arşivlenebilmektedir. $\mathrm{Bu}$ süreçte yönetici herhangi bir deney setini seçmeden uygulamayı başlatırsa, öğrenci masadaki kart okuyucuya kimlik kartını okutması ile, sistem veri tabanından öğrencinin aldığ dersleri kontrol edip, sadece öğrencinin aldığı dersler ile ilgili deney setlerinin enerjilenmesine izin vermektedir.

$\mathrm{Bu}$ çalışma kapsamında hazırlanan program ile yoklama arşivi veri tabanından incelenebildiği gibi, geçmiş tarihli uygulamalar da veri tabanından çekilebilmektedir. Uygulama arşivi sekmesi ile geçmiş tarihte, hangi derste hangi öğrenci hangi saatler arasında, hangi deney seti ile çalışmış görülebilmektedir. Bu sürecin yönetimi için uygulama arşivi sekmesinden istenilen tarih ve dersin seçilmesi yeterlidir. Ayrıca bu doküman çıktı olarak ta alınabilmektedir. Bu sekmeye dair ekran görüntüsü Şekil 5’te görülmektedir.

Her yıl yeni öğrencilerin laboratuvarı kullanmaya başlaması ile veri tabanına yeni öğrencilerin bilgileri eklenmesi de gerekmektedir. Bu çalışma kapsamında hazırlanan program, üniversite veri tabanı ile uyumlu çalışabilmesi için uygun altyapıya sahiptir. Ancak kişisel verilerin korunması amac1 ile, bu program ticari bir ürün haline gelmeden önce veriler öğrencilerin kendisi tarafından girilmesi gerekmektedir. Veri tabanına yeni kayıt yapılacak öğrencinin, kimlik kartını kapıda bulunan kart okuyucuya okutması gerekmektedir. Öğrenci kayıt sekmesinde bulunan boşluklar öğrenci bilgileri ile doldurularak, öğrencinin ve kimlik kartının veri tabanına kaydı gerçekleşmektedir. "Öğrenci kayıt" sekmesi Şekil 5'de görülmektedir. 


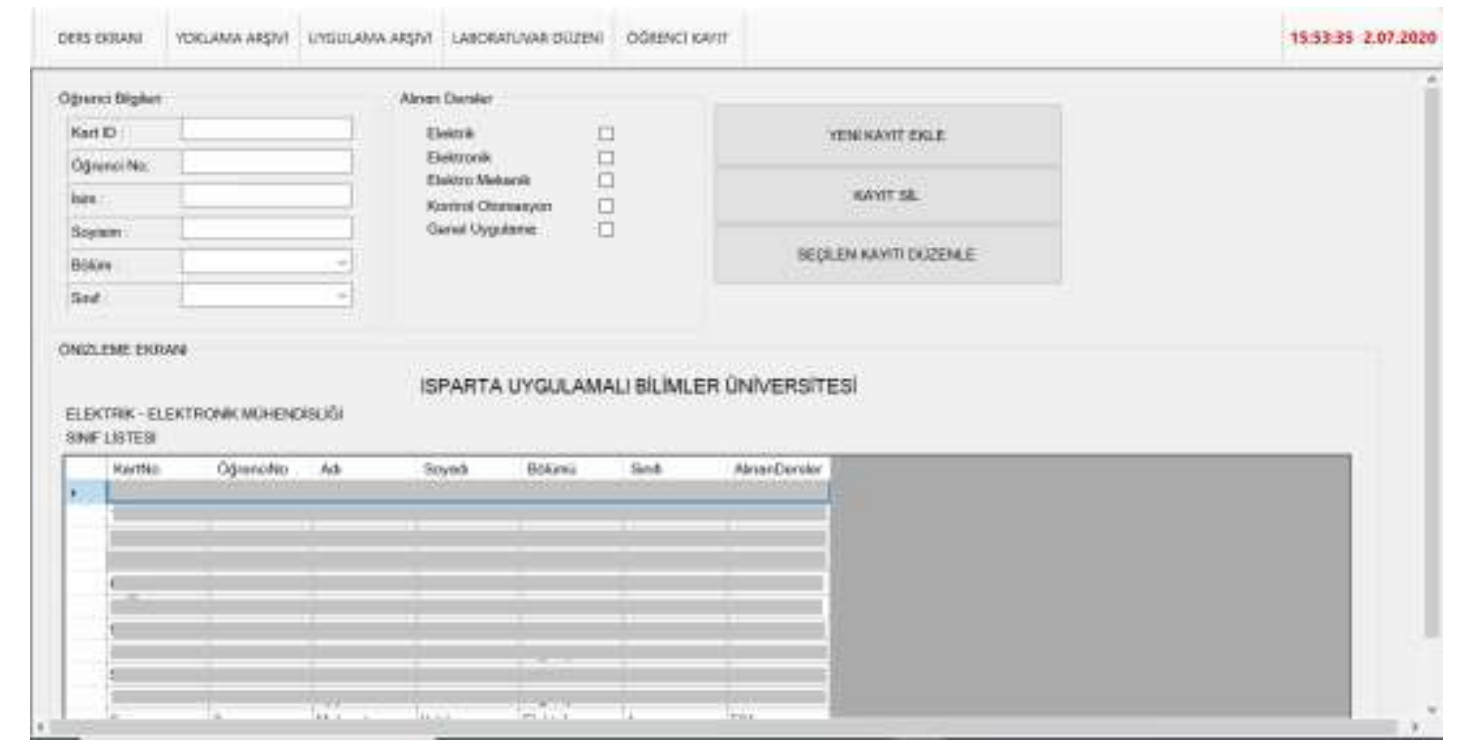

Şekil 5. Öğrenci kayıt ekranı

\subsection{Sistemin Uygulaması ve Test Sürecinin Değerlendirilmesi}

$\mathrm{Bu}$ çalışma kapsamında yazılımı ve donanımı hazırlanan laboratuvar otomasyon sisteminin uygulaması Mehmet Akif Ersoy Üniversitesi, Bucak Emin Gülmez Teknik Bilimler MYO'da elektronik laboratuvarında yapılmıştır. Meslek yüksekokuluna ait laboratuvar görüntüsü Şekil 6’da görülmektedir.

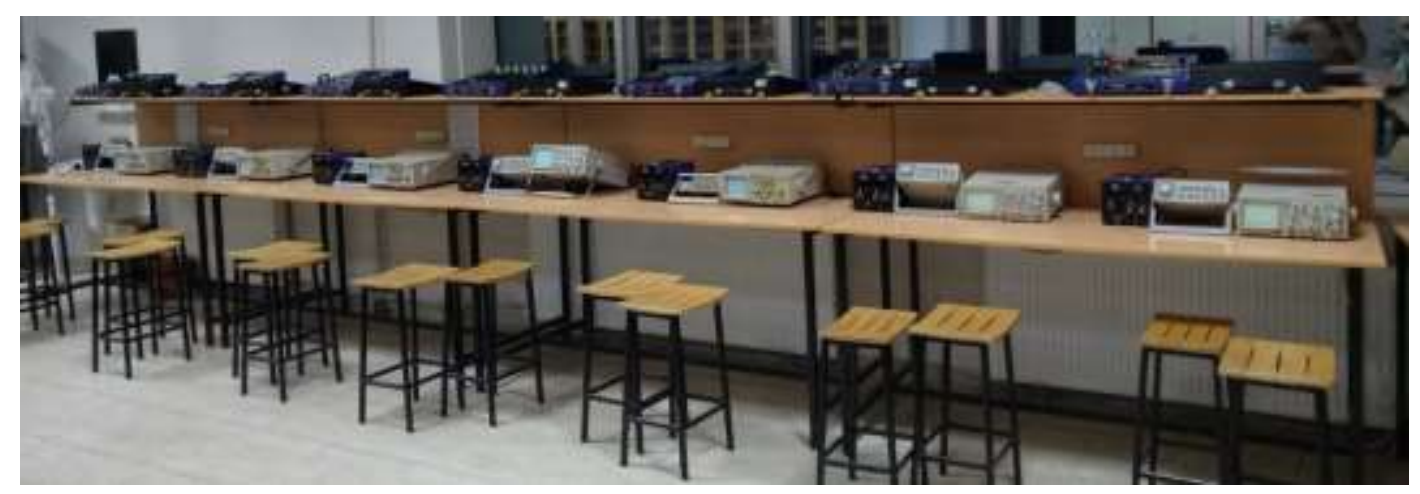

Şekil 6. Emin Gülmez TBMYO elektronik laboratuvarı

Bu çalışma kapsamında hazırlanan laboratuvar otomasyon sistemi, çalışmanın sadece teoride kalmaması için bir eğitim öğretim dönemi, yani 13 haftalık bir süreçte mevcut MYO öğrencileri ile uygulanmıştır. 13 haftalık deneme sürecinde laboratuvar otomasyon sistemine dair eksikler giderilmiş, hatalar ayıklanmış ve ihtiyaç duyulan özellikler gözlenerek sisteme eklenmiştir. Uygulamalı eğitim ile adapte olan laboratuvar otomasyon sistemi, birçok yönden laboratuvar cihazlarının takibine olanak sağlamış. İnceleme yapılan 13 haftalık süreç cihazların ve öğrencilerin takibine yönelik çalışmalara 1şık tutmuştur. 
Çalışma kapsamında, elektronik laboratuvarında bulunan 8 masanın kontrolü ve izlenmesi sağlanmış olup, bazı küçük revizyonlar ile daha büyük laboratuvarlar için bu sistem uyumlu hale getirilebilir durumdadır. Şekil 7'de 8 masa ve bir yönetici masası için hazırlanan sisteme dair şema görülmektedir.

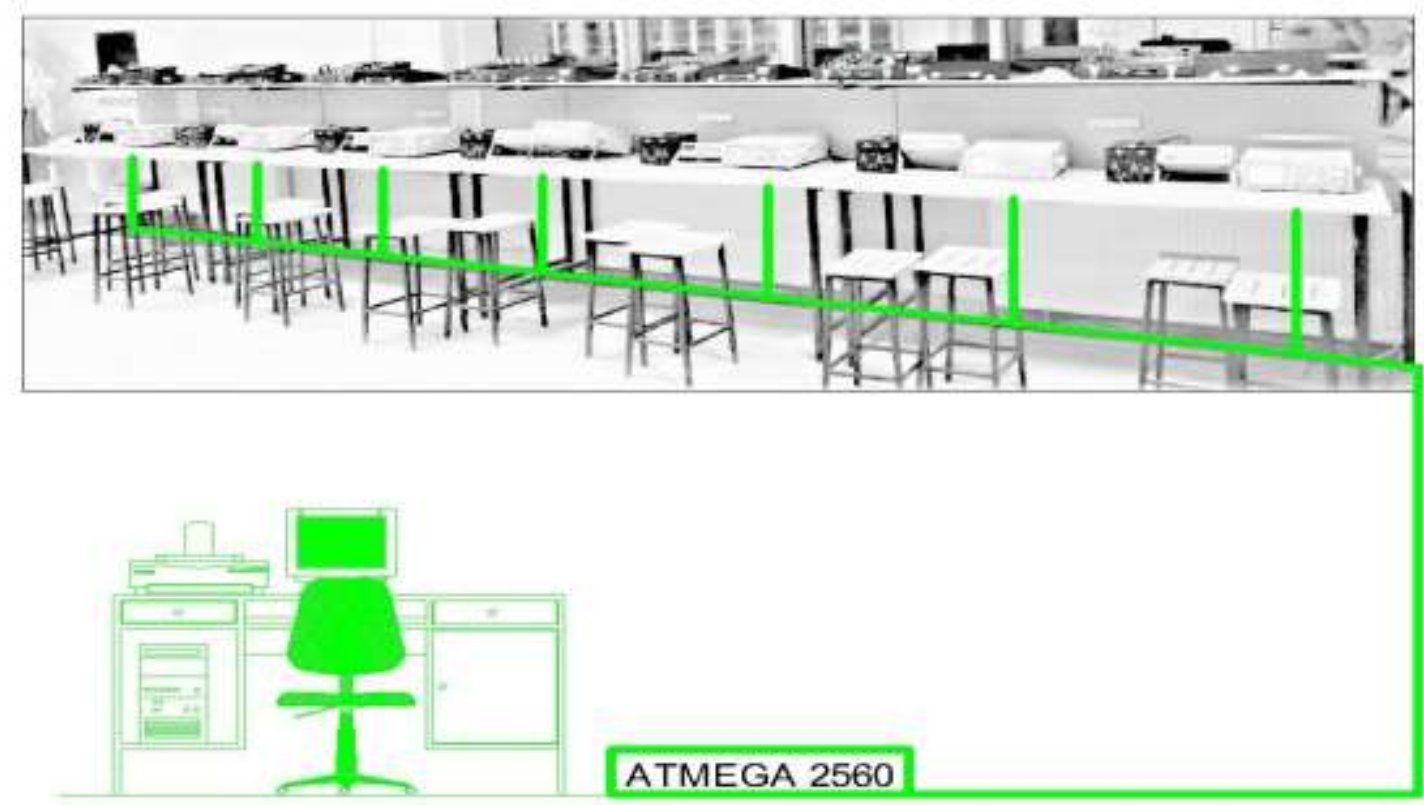

Şekil 7. Laboratuvar otomasyon sistemi genel şemas1

Meslek yüksekokulu laboratuvarında gerçekleştirilmiş olan 13 haftalık gözlem sürecinde temel elektronik uygulama dersinde izlenen deney süreci Tablo 1'de verilmiştir. Yüksekokul laboratuvarında bulunan 4 farklı deney ekipmanının her bir deney için farklı bir kullanım kombinasyonuna sahip olduğu görülmektedir. $\mathrm{Bu}$ ekipmanlara dair kullanım istatistikleri ve öğrencilerin deneyler için harcadıkları süreler bu çalışma kapsamında arşivlenebilmiştir. Farklı bir laboratuvar için laboratuvar otomasyon sistemi kullanılması durumunda yine farklı laboratuvar ekipmanlarının da enerji kontrolü sağlanabilecek şekilde bir tasarım yapılmıştır. Böylelikle kontrol laboratuvarı, sayısal elektronik laboratuvarı, bilgisayar laboratuvarı, otomasyon laboratuvarı ve güç elektroniği laboratuvarı gibi birçok uygulamalı ders için uyumlu çalışabilir bir sistem geliştirilmiştir. 
Tablo 1. Haftalık deney konuları ve kullanılan cihazlar

\begin{tabular}{|c|c|c|c|c|c|c|}
\hline Hafta & Konu/Deney & Grup & $\begin{array}{l}\text { DC Güç } \\
\text { kaynağı }\end{array}$ & $\begin{array}{l}\text { Sinyal } \\
\text { üreteci }\end{array}$ & Osiloskop & $\begin{array}{c}\text { Multimetr } \\
\text { e }\end{array}$ \\
\hline 1. & Elektronik Laboratuvarı ve Cihazları Tanıma & 1 ve 2 & $\mathrm{x}$ & $\mathrm{x}$ & $\mathrm{x}$ & $\mathrm{X}$ \\
\hline 2. & $\begin{array}{l}\text { Diyotun Sağlamlık Kontrolü ve Karakteristik Eğrisinin } \\
\text { Çıkartılması }\end{array}$ & 1 & $\mathrm{x}$ & & & $\mathrm{X}$ \\
\hline 3. & $\begin{array}{l}\text { Diyotun Sağlamlık Kontrolü ve Karakteristik Eğrisinin } \\
\text { Çıkartılması }\end{array}$ & 2 & $\mathrm{x}$ & & & $\mathrm{X}$ \\
\hline 4. & Doğrultmaç Devreleri & 1 & & & $\mathrm{x}$ & $\mathrm{X}$ \\
\hline 5. & Doğrultmaç Devreleri & 2 & & & $\mathrm{x}$ & $\mathrm{X}$ \\
\hline 6. & Kırpıcı ve Kenetleyici Devreler & 1 & & $\mathrm{x}$ & $\mathrm{x}$ & \\
\hline 7. & Kırpıcı ve Kenetleyici Devreler & 2 & & $\mathrm{x}$ & $\mathrm{x}$ & \\
\hline 8. & Zener Diyotlu Gerilim Regüle Devreleri & 1 & $\mathrm{x}$ & $\mathrm{x}$ & $\mathrm{x}$ & $\mathrm{X}$ \\
\hline 9. & Zener Diyotlu Gerilim Regüle Devreleri & 2 & $\mathrm{x}$ & $\mathrm{x}$ & $\mathrm{x}$ & $\mathrm{X}$ \\
\hline 10. & $\begin{array}{l}\text { Transistör DC Akım kazancının belirlenmesi, Çalışma } \\
\text { Noktasının Tespiti ve Yükselteç Devresi Tasarımı }\end{array}$ & 1 & $\mathrm{x}$ & & & $X$ \\
\hline 11. & $\begin{array}{l}\text { Transistör DC Akım kazancının belirlenmesi, Çalışma } \\
\text { Noktasının Tespiti ve Yükselteç Devresi Tasarımı }\end{array}$ & 2 & $\mathrm{x}$ & & & $X$ \\
\hline 12. & Op-Amp Deneyleri & 1 & $\mathrm{x}$ & $\mathrm{x}$ & $\mathrm{x}$ & $\mathrm{X}$ \\
\hline 13. & Op-Amp Deneyleri & 2 & $\mathrm{x}$ & $\mathrm{x}$ & $\mathrm{x}$ & $\mathrm{X}$ \\
\hline
\end{tabular}

Bu çalışma kapsamında hazırlanan ve meslek yüksekokulu elektronik laboratuvarında 13 haftalık süreçte uygulamalı olarak denenen sistem, öğrencilerin hangi deney için ne kadar süre harcadıklarını gözlemleyebilmeyi ve arşivleyebilmeyi sağlamaktadır. Aynı zamanda elektrik bölümü öğrencileri için temel elektronik dersi bir dönemlik laboratuvar kayıtları görülebilmektedir. Tablo aynı zamanda, öğrencilerin de uygulama dersi için harcadıkları süreleri göstermektedir. Böylelikle temel elektronik uygulama dersi haftalık deney süreleri izlenebilmekte, bu takibe göre hangi deneyin öğrenciler tarafindan uzun sürelerde, hangi deneylerin öğrenciler tarafından daha kısa sürelerde yapıldığı gözlemlenebilmiştir. Bu gözlemler bir sonraki ders dönemi uygulanacak deney föyleri için dersi veren akademisyene yol gösterici olacaktır.

Laboratuvar otomasyon sistemi, farklı birçok ders için bu gözlemi yapma imkânı sağlamaktadır. Bu gözlem ile, bir sonraki dönem uygulama dersleri daha verimli işlenebilecek ve veri tabanına kaydedilen arşiv sayesinde önceki yıllara dair uygulamalar ile kıyaslama imkânı sunacaktır. Şekil 8'de elektrik bölümü öğrencilerinin temel elektronik laboratuvarı dersinde yaptıkları çalışmaların dönemlik grafiği verilmiştir. Bu grafik göstermektedir ki, 4-5 haftalarında yapılan "doğrultmaç devreleri”" deneyi ve 10-11 haftalarında yapılan "Transistör DC Akım kazancının belirlenmesi, Çalışma Noktasının Tespiti ve Yükselteç Devresi Tasarımı” 
deneyleri diğer haftalara göre daha kısa sürmüştür. Bu bilgiler de göstermektedir ki, bir sonraki y1l bu deneyler daha kompleks bir uygulama ile güçlendirilebilir.

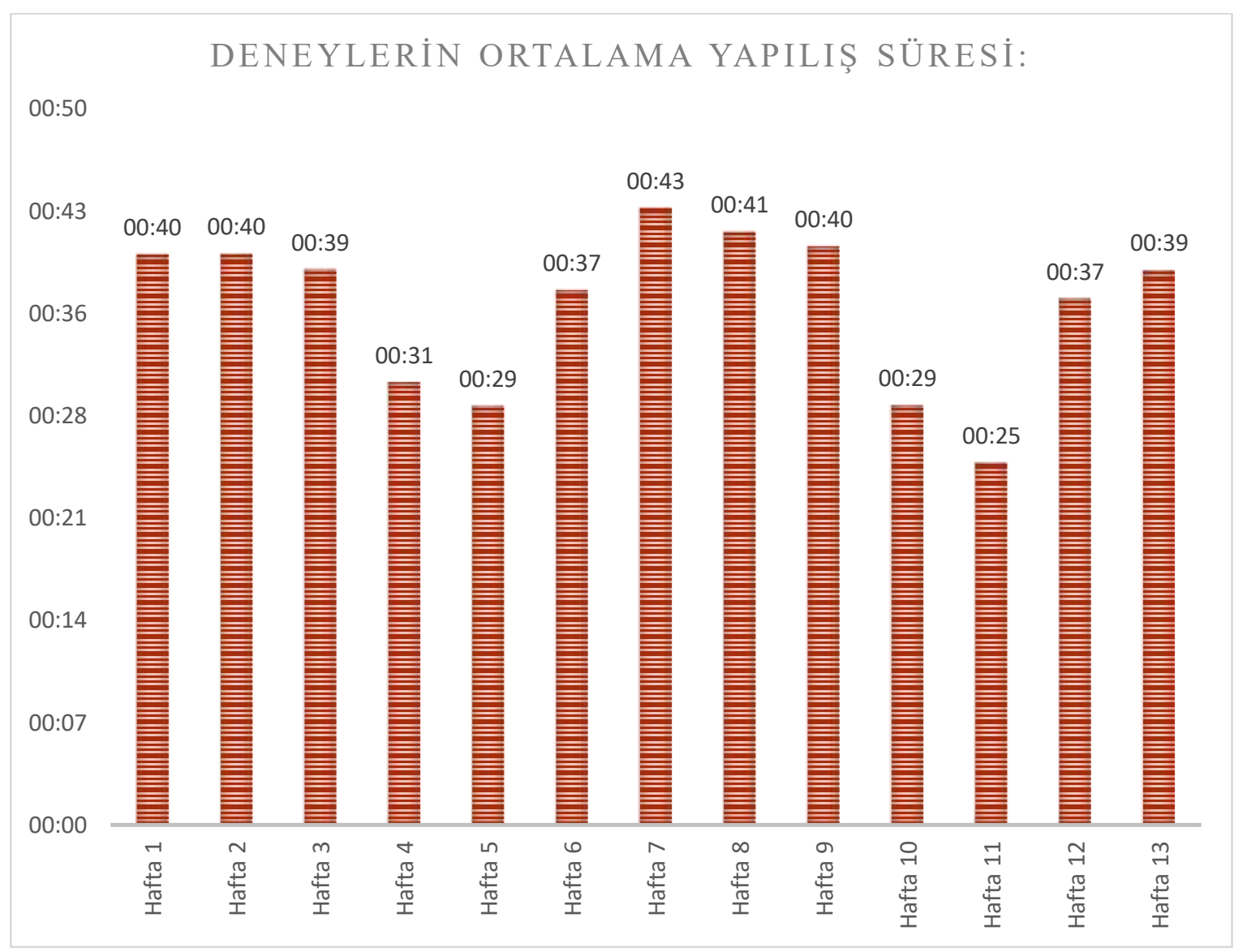

Şekil 8. Öğrencilerin haftalık ortalama uygulama ve deney süreleri

Laboratuvar otomasyonu veri tabanında arşivlemesi yapılan bir diğer kısım ise, öğrenciler ve öğrencilerin çalıştı̆̆ı ekipmanların kaydıdır. Öğrencilerin ekipmanlar ile çalışma süreçlerinin kayıt altına alınması, ekipmanın arıza takibi ve denetimini kolaylaştırmaktadır. Temel elektronik laboratuvarı ve elektrik bölümü öğrencileri ile yapılan bir dönemlik gözlem ve uygulama süreci, ekipmanların arızasız olarak dönemi bitirmesi ile sonuçlanmıştır. Laboratuvar otomasyon sistemi kurulmadan önceki yıllara ait cihaz arıaları ile ilgili kayıt bulunmamaktadır. Ancak önceki yıllardan âtıl vaziyette arızalı ve kaydı tutulmamış osiloskop, güç kaynağı ve sinyal üreteçleri bulunmaktadır. Bu durum da göstermektedir ki, cihaz kullanımının kayıt altına alınması, laboratuvar ekipmanlarının daha titiz kullanımını sağlamaktadır. Tablo 2'de bir dönem boyunca, hangi masada hangi öğrencinin çalışma yaptığ tablo olarak gösterilmiştir. 
Tablo 2. Öğrencilerin deney setlerinde çalışma süreleri

\begin{tabular}{|c|c|c|c|c|c|c|c|c|}
\hline & SET 1 & SET 2 & SET 3 & SET 4 & SET 5 & SET 6 & SET 7 & SET 8 \\
\hline \multirow[t]{2}{*}{ HAFTA 1} & $* * * * * * * * * 1$ & $* * * * * * * * * 5$ & $* * * * * * * * * 7$ & $* * * * * * * * * 1$ & $* * * * * * * * * 9$ & $* * * * * * * * * 3$ & $* * * * * * * * * 1$ & $* * * * * * * * * 7$ \\
\hline & 00:00:00 & $00: 32: 18$ & $00: 49: 35$ & $00: 42: 00$ & $00: 36: 50$ & $00: 39: 16$ & $00: 29: 47$ & $00: 21: 40$ \\
\hline \multirow[t]{2}{*}{ HAFTA 1} & $* * * * * * * * * 8$ & $* * * * * * * * * 4$ & $* * * * * * * * * 6$ & $* * * * * * * * * 0$ & $* * * * * * * * * 2$ & $* * * * * * * * * 2$ & $* * * * * * * * *$ & $* * * * * * * * * 66$ \\
\hline & $00: 46: 30$ & $00: 25: 24$ & $00: 46: 43$ & $00: 29: 18$ & $00: 58: 58$ & $00: 19: 16$ & 00:11:08 & $00: 10: 25$ \\
\hline \multirow[t]{2}{*}{ HAFTA 2} & *********1 1 & $* * * * * * * * * 5$ & **********7 7 & $* * * * * * * * * 1$ & $* * * * * * * * * 9$ & $* * * * * * * * * 3$ & $* * * * * * * * * 1$ & $* * * * * * * * * 7$ \\
\hline & $00: 45: 56$ & $00: 33: 14$ & $00: 25: 24$ & $00: 35: 53$ & $00: 37: 05$ & 00:00:00 & $00: 25: 17$ & \\
\hline \multirow[t]{2}{*}{ HAFTA 3} & *********8 8 & $* * * * * * * * * 4$ & *********6 & *********0 & *********2 2 & *********2 & $* * * * * * * * *$ & $* * * * * * * * * 6$ \\
\hline & $00: 37: 57$ & 00:43:04 & $00: 27: 23$ & $00: 17: 26$ & $00: 44: 16$ & $00: 33: 31$ & $00: 43: 36$ & $00: 54: 57$ \\
\hline \multirow[t]{2}{*}{ HAFTA 4} & *********1 1 & $* * * * * * * * * 5$ & *********7 & $* * * * * * * * 1$ & *********99 & *********3 3 & $* * * * * * * * * 1$ & $* * * * * * * * 7$ \\
\hline & $00: 51: 22$ & $00: 49: 35$ & $00: 44: 16$ & $00: 41: 42$ & $00: 12: 32$ & $00: 47: 54$ & 00:59:19 & \\
\hline \multirow[t]{2}{*}{ HAFTA 5} & $* * * * * * * * * 8$ & $* * * * * * * * * 4$ & $* * * * * * * * * 6$ & *********0 & $* * * * * * * * * 2$ & $* * * * * * * * * 2$ & $* * * * * * * * *$ & $* * * * * * * * 6$ \\
\hline & $00: 41: 40$ & $00: 49: 27$ & $00: 37: 06$ & $00: 44: 54$ & $00: 56: 21$ & $00: 29: 19$ & $00: 45: 53$ & $00: 43: 24$ \\
\hline \multirow[t]{2}{*}{ HAFTA 6} & $* * * * * * * * * 1$ & $* * * * * * * * * 5$ & $* * * * * * * * * 7$ & $* * * * * * * * * 1$ & $* * * * * * * * * 9$ & $* * * * * * * * * 3$ & $* * * * * * * * * 1$ & $* * * * * * * * * 7$ \\
\hline & $00: 41: 05$ & $00: 37: 13$ & $00: 25: 24$ & $00: 42: 27$ & $00: 28: 11$ & $00: 55: 24$ & $00: 45: 13$ & \\
\hline \multirow[t]{2}{*}{ HAFTA 7} & $* * * * * * * * * 8$ & $* * * * * * * * * 4$ & $* * * * * * * * * 6$ & $* * * * * * * * * 0$ & $* * * * * * * * * 2$ & $* * * * * * * * * 2$ & $* * * * * * * * * *$ & $* * * * * * * * * 6$ \\
\hline & $00: 26: 37$ & $00: 51: 14$ & 00:00:00 & $00: 29: 35$ & 00:54:47 & $00: 51: 22$ & $00: 56: 32$ & $00: 48: 00$ \\
\hline \multirow[t]{2}{*}{ HAFTA 8} & $* * * * * * * * * 1$ & $* * * * * * * * * 5$ & $* * * * * * * * * 7$ & $* * * * * * * * * 1$ & $* * * * * * * * * 9$ & $* * * * * * * * * 3$ & **********1 & $* * * * * * * * * 7$ \\
\hline & $00: 45: 24$ & $00: 44: 19$ & $00: 42: 27$ & $00: 32: 18$ & $00: 27: 55$ & $00: 37: 57$ & $00: 38: 31$ & \\
\hline \multirow[t]{2}{*}{ HAFTA 9} & ***********8 & $* * * * * * * * * 4$ & $* * * * * * * * * 6$ & $* * * * * * * * * 0$ & $* * * * * * * * * 2$ & $* * * * * * * * * 2$ & $* * * * * * * * *$ & $* * * * * * * * * 6$ \\
\hline & $00: 58: 58$ & $00: 25: 47$ & $00: 22: 06$ & $00: 55: 46$ & $00: 29: 42$ & $00: 46: 30$ & $00: 55: 46$ & $00: 32: 18$ \\
\hline \multirow[t]{2}{*}{ HAFTA 10} & $* * * * * * * * * 1$ & $* * * * * * * * * 5$ & $* * * * * * * * * 7$ & $* * * * * * * * * 1$ & $* * * * * * * * * 9$ & $* * * * * * * * * 3$ & $* * * * * * * * * 1$ & $* * * * * * * * * 7$ \\
\hline & $00: 48: 26$ & $00: 40: 52$ & $00: 45: 56$ & $00: 49: 35$ & $00: 48: 25$ & $00: 25: 51$ & $00: 24: 11$ & \\
\hline \multirow[t]{2}{*}{ HAFTA 11} & $* * * * * * * * * 8$ & $* * * * * * * * * 4$ & $* * * * * * * * * 6$ & $* * * * * * * * * 0$ & $* * * * * * * * * 2$ & $* * * * * * * * * 2$ & $* * * * * * * * *$ & $* * * * * * * * * 6$ \\
\hline & 00:54:04 & $00: 35: 32$ & 00:11:32 & 00:20:19 & 00:00:00 & $00: 24: 33$ & $00: 10: 25$ & 00:45:03 \\
\hline \multirow[t]{2}{*}{ HAFTA 12} & $* * * * * * * * * 1$ & $* * * * * * * * * 5$ & $* * * * * * * * * 7$ & $* * * * * * * * * 1$ & $* * * * * * * * * 9$ & $* * * * * * * * * 3$ & $* * * * * * * * * 1$ & $* * * * * * * * * 7$ \\
\hline & $00: 44: 16$ & $00: 42: 27$ & $00: 37: 13$ & $00: 29: 35$ & $00: 51: 49$ & 00:00:00 & $00: 32: 08$ & \\
\hline \multirow[t]{2}{*}{ HAFTA 13} & $* * * * * * * * * 8$ & $* * * * * * * * * 4$ & $* * * * * * * * * 6$ & $* * * * * * * * * 0$ & $* * * * * * * * * 2$ & $* * * * * * * * * 2$ & $* * * * * * * * *$ & $* * * * * * * * * 6$ \\
\hline & $00: 44: 16$ & $00: 42: 27$ & $00: 37: 13$ & $00: 29: 35$ & $00: 51: 49$ & 00:00:00 & 00:32:08 & $00: 58: 26$ \\
\hline
\end{tabular}

Laboratuvar otomasyon sistemi çalışması kapsamında hazırlanan veri tabanından öğrencilerin ve ekipmanların arşivlenen verileri aynı zamanda cihaz ve ekipman kullanımında ömür takibi yapmayı da sağlamaktadır. Tablo 3'de bir dönem boyunca hangi ekipmanın toplam ne kadar süre çalıştığına dair bilgi vermektedir.

Tablo 3. Laboratuvar ekipmanların kullanım süreleri

\begin{tabular}{|l|l|l|l|l|l|l|l|l|}
\hline & Set 1 & Set 2 & Set 3 & Set 4 & Set 5 & Set 6 & Set 7 & Set 8 \\
\hline Sinyal üreteci & $06: 28$ & $05: 54$ & $07: 54$ & $05: 45$ & $06: 43$ & $05: 28$ & $04: 50$ & $02: 12$ \\
\hline Osiloskop & $04: 36$ & $05: 03$ & $06: 44$ & $05: 19$ & $05: 51$ & $04: 15$ & $04: 41$ & $02: 38$ \\
\hline Multimetre & $05: 52$ & $05: 40$ & $07: 45$ & $06: 42$ & $06: 57$ & $05: 29$ & $05: 33$ & $03: 35$ \\
\hline DC Güç kaynă̆ı & $07: 44$ & $06: 31$ & $08: 55$ & $07: 08$ & $07: 49$ & $06: 42$ & $05: 54$ & $04: 04$ \\
\hline
\end{tabular}




\section{SONUÇ}

$\mathrm{Bu}$ çalışma kapsamında ayrıca hazırlanan laboratuvar otomasyon sistemi ile bir elektronik laboratuvarının bir dönemlik ders ve uygulama süreci izlenmiştir. Laboratuvar otomasyon sisteminin yazılım kısmını C\#, .Net, Visual Studio oluştururken, donanım kısmı için mikrodenetleyici olarak Atmega 2560 işlemciden faydalanılmıştır. Ayrıca otomasyon sistemi için RFID kart okuyucular ve röleler kullanılmıştır.

Laboratuvar otomasyon sisteminin bir dönemlik takibi ile, öğrencilere ait yoklama verileri, öğrencilere ait deney seti ve laboratuvar ekipmanları kullanım verileri, laboratuvar ekipmanlarının kullanım sürelerine dair veriler veri tabanına kaydedilmiştir.

Tüm bu verilerin veri tabanına kayıt edilmesi ile; öğrencilerin yoklama takibi dijital ortamda gerçekleştirilebilmiştir. Laboratuvar cihazlarının kullanım süreleri takip altına alınmış ve bu veriler, takip edilen deney föylerinin geliştirilmesi adına katkıda bulunmuştur. Öğrencilerin deneyleri yaparken kullandığı ekipmanların kayıt altına alınıyor olması, cihazların daha özenli kullanımını sağlamış ve arızalı âtıl vaziyette durabilecek laboratuvar ekipmanlarının önüne geçilmiştir.

14 Haftalık süresince 4 farklı laboratuvar cihazında kısa devre akımlarına bağlı arızalar oluşmuş, bu arızaların giderilmesi, yine arıza oluşumuna neden olan öğrenciler tarafından sağlanmıştır. Böylelikle, bu çalışma uygulanmadan önce kayıt altına alınmış olan 14 haftalık süreçteki 11 ekipman arızası 4 arızaya düşürülmüş bulunmaktadır. Haftalık 0,78 adet olan arıza istatistiğinin 0,28 adet olarak azaltılması laboratuvar ekipmanlarındaki arızalanma oranının \%64 azaldığını göstermektedir. Ayrıca ekipmanlardaki arızaların aynı süreçte giderilmiş olması, bu tez çalışmasının olumlu sonuç verdiğinin göstergesidir.

\section{REFERENCES / KAYNAKLAR}

Akdeniz, H. Y. (2019). Arduino tabanlı mppt solar şarj kontrolörü tasarımı ve uygulaması (Yüksek lisans tezi). Afyon Kocatepe Üniversitesi, Afyon.

Akkaya, A. (2019). Yüz, parmak izi, rfid ve karekodlu entegre geçiş kontrol sistemi tasarım ve uygulaması (Yüksek lisans tezi). Karabük Üniversitesi, Karabük.

Aktan, B., Bohus, C. A., Crowl, L. A. \& Shor, M. H. (1996). Distance learning appiled to control engineering laboratories. IEEE Transactions on Industrial Electronics, 39(3), 320-326.

Alexander, P. J. \& Radhakrishnan, N. (2015). Remote lab implementation on an embedded web server. International Conference on Circuit, Power and Computing Technology, March 19-20, Nagercoil, India. 
Anli, G. (2019). CT ve MRI görüntülerinden matlab ortamında vücut uzuvlarının üç boyutlu modellerinin elde edilmesi ve örnek uygulama (Yüksek lisans tezi). Sakarya Uygulamalı Bilimler Üniversitesi, Sakarya.

Anonim. (2019b). Make block dc motors. Erişim tarihi: 02.12.2019, https://www.makeblock.com/project/dcmotor-25-6v

Anonim. (2019b). Maxim Integrated. Erişim tarihi: 02.12.2019, https://www.maximintegrated.com/en/sitesearch.html\#q=ds1307\&sort=relevancy

Anonim. (2019b). Net framework. Erişim tarihi: 02.12.2019, http://msdn.microsoft.com/trtr/library/hh425099(v=vs.110).aspx

Anonim. (2019b). ST microelectronics. Erişim tarihi: 22.11.2019, https://www.st.com/content/st_com/en.html

Anonim. (2020b). $\quad S T \quad$ microelectronics. $\quad$ Erişim $\quad$ tarihi: http://www.st.com/web/catalog/tools/FM147/CL1794/SC961/SS1533/PF258513?sc=stm32-mat-target

Anonim. (2020b). Waijung blockset. Erişim tarihi: 03.05.2020, http://waijung.aimagin.com/

Arakliotis, S., Nikolos, D. G., Kalligeros, E. \& Lawris, A. (2016). Rule-based arduino programming system for young students. 5th International Conference on Modern Circuits and Systems Technologies, May 12-14, Thessaloniki, Greece.

Arıcı, İ. (2014). Labvıew tabanlı bir elektronik deney seti geliştirilmesi (Yüksek lisans tezi). Muğla Sıtkı Koçman Üniversitesi, Muğla.

Barrera, A. H. (2014). Teaching introduction to robotics: Using a blend of problem and project-based learning approaches. IEEE, March 13-16, Southeastcon, Lexington, USA.

Başaran, B. (2018). Arduino'nun elektrik deneylerine entegre edilmesinin ve deney raporlarının poster şeklinde hazırlanmasının, fen bilgisi öğretmen adaylarının fizik laboratuvarlarına, teknolojiye ve bilgi ve iletişim teknolojilerine yönelik tutumlarına etkisinin incelenmesi (Yüksek lisans tezi). Kocaeli Üniversitesi, Kocaeli.

Batan, E. (2015). Matlab simulink ortamında kullanılabilen arduino temelli kontrol deney seti tasarımı (Yüksek lisans tezi). Tarsus Üniversitesi, Mersin.

Baydar, R. (2018). Bir gaz türbini enerji analizinin matlab/simulink ile modellenmesi (Yüksek lisans tezi). Kırıkkale Üniversitesi, Kırıkkale.

Bermudez-Ortega, J., Besada-Portas, E., Lopez-Orozco, J. A. \& De La Cruz, J. M. (2015). Remote web-based control laboratory for mobile devices based on EJsS, raspberry pi and node.js. IFAC-PapersOnLine, 48, 158-163.

Chang, C., C. \& Lo, Y. C. (2006). Broadband RFID tag antenna with capacitively coupled structure. Electron Lett., $42,1322-1323$.

Curtin, J., Kauffman, R. J. \& Riggins, F. J. (2007). Making the “MOST”, out of RFID technology: A research agenda for the study of the adoption, usage, and impact of RFID. Information Technology and Management, $8(2)$, 87-110.

Çakar, M. (2016). Lokal geoit üzerine C sharp programlama dilinde uygulama (Yüksek lisans tezi). Aksaray Üniversitesi, Aksaray.

Çepni, S. \& Özmen, H. (2010). Kuramdan uygulamaya fen ve teknoloji öğretimi (10. Baskl). Ankara: Pegem Akademi Yayıncılık.

Çiftçi, S. (2011). Matlab (İkinci Baskı). İstanbul: Kodlab Yayıncılık.

Dökmetaş, G. (2016). Arduino eğitim kitabı. İstanbul: Dikeyeksen Yayıncılık. 


\section{Yoldaş, F. \& Şenol, R.}

El-Abd, M. (2017). A review of embedded systems education in the arduino age: Lessons learned and future directions. International Journal of Engineering Pedagogy, 7(2), 79-93.

Garip, İ. (2008). Alternatörlerin otomatik paralel bağlanmast için eğitim amaçlı bir deney setinın geliştirilmesi ve etkililiğinin değerlendirilmesi (Doktora tezi). Gazi Üniversitesi, Ankara.

Gupta, N., Tejovanth, N. \& Murthy, P. (2012). Learning by creating: Interactive programming for Indian high schools. International Conference on Technology Enhanced Education (ICTEE), January 03-05, Surathkal, India.

Gülcan, R. (2019). Uzaktan kontrollü arm tabanlı mikrodenetleyici deney seti tasarımı ve gerçekleştirilmesi (Yüksek lisans tezi). Akdeniz Üniversitesi, Antalya.

Günaydın, R. (2014). Uzaktan erişimli web tabanlı mikrodenetleyici deney seti tasarımı ve gerçekleştirilmesi (Yüksek lisans tezi). Karabük Üniversitesi, Karabük.

Hentrup, A. A., Lu, D. \& Roldan, P. R. (2016). Wireless authentication of smart doors using RFID (Honors thesis). Loyola Marymount University, ABD.

Herger, M. L. (2015). Engaging students with open source technologies and arduino. 5th IEEE Integrated STEM Conference, March 07, Princeton, New Jersey.

Hoffer, B. M. (2012). Satisfying STEM education using the arduino microprocessor in C programming (Yüksek lisans tezi). East Tennessee State University, ABD.

Irmak, E. \& Calpbinici, A. (2017). E-laboratuvarlar için yeni bir tasarım: Eş zamanlı erişilebilen deneysel uygulama platformu. Journal of the Faculty of Engineering and Architecture of Gazi University, 32, 363-375.

Jamieson, P. (2017). Arduino for teaching embedded systems. Are computer scientists and engineering educators missing the boat? CiteSeerX, doi=10.1.1.217.7157

Kaçar, S., Boz, A. F., Arıcıoğlu, B. \& Tekin, H. (2016). PID denetleyici uygulamaları için yeni bir online deney seti tasarımı. Sakarya Üniversitesi Fen Bilimleri Enstitüsü Dergisi, 21(1), 34-46. doi: 10.16984/saufenbilder.12551

Kamilov, M., Hudayberdiev, M. \& Khamroev, A. (2018). Algorithm for the development of a training set that best describes the objects of recognition. XIII. International Symposium “Intelligent Systems” (INTELS'18).

Medin, G. L. \& Petric, M. (2015). Embedded lab: Arduino projects in science lessons. 4th Mediterranean Conference on Embedded Computing, June 14-18, Budva, Montenegro.

Merino, P. P., Ruiz, E. S., Fernandez, G. C. \& Gil, M. C. (2016). Robotic educational tool to engage students on engineering. XII Technologies Applied to Electronics Teaching Conference, June 22-24, Seville.

Mutlu, A. \& Sürmeli, C. (2015). Mikrodenetleyiciler ile seri iletişim. İstanbul: Kodlab Yayıncılık.

Nath, B., Reynolds, F. \& Want, R. (2006). RFID technology and applications. IEEE Pervasive Computing, 5(1), 22-24.

Ovatman, T., Brekling, A. W. \& Hansen, M. R. (2010). Cost analysis for embedded systems: Experiments with priced timed automata. Electronic Notes in Theoretical Computer Science, 238(6), 81-95.

Ömürlü, V. Ö. (2020). Otomatik kontrol I. p(oransal) i(integral) d(türevsel) kontrol. Erişim tarihi: 07.05.2020, https://docplayer.biz.tr/271952-Otomatik-kontrol-i-p-oransal-i-integral-d-turevsel-kontrol-dr-vasfi-emreomurlu.html

Özbek, M. (2014). Temel haberleşme laboratuvarı için bilgisayar destekli modülasyon demodülasyon deney seti (Yüksek lisans tezi). Gazi Üniversitesi, Ankara. 
Parladır Karcı, A. (2018). Uzaktan algllama ve coğrafi bilgi sistemlerinin sulama şebekelerinin performans değerlendirmesinde kullanılması: Atabey sulama şebekesi örneği (Yüksek lisans tezi). Isparta Uygulamalı Bilimler Üniversitesi, Isparta.

Sarıkaş, A. \& Yayla, A. (2017). Uzaktan erişimli mikrodenetleyici laboratuvarı. Journal of Research in Education and Teaching, 6, 283-296.

Shaikh, S. A. (2015). Two axis direction finding antenna system using difference-sum patterns in $x$-band (Yüksek lisans tezi). Sabancı Üniversitesi, Sakarya.

Shim, J., Ko, j. \& Shim, J. (2014). A study on training courses development and analysis for improving the creativity using arduino. Journal of Korea Multimedia Society, 17(4), 514-525.

Soriano, A., Marin, L., Valles, M., Valera, A. \& Albertos, P. (2014). Low cost platform for automatic control education based on open hardware. Preprints of the 19th World Congress The International Federation of Automatic Control, August 24-29, Cape Town, South Africa.

Süzen, A. A. \& Taşdelen, K. (2018). Havalimanları için bagaj teslimat sistemi. SDU International Journal of Technological Sciences, 10(2), 14-21.

Şimşek, M. A. (2015). Arduino kart ile tasarlanmış sistemlerin internet tabanlı kontrolü ve izlenmesi (Yüksek lisans tezi). Süleyman Demirel Üniversitesi, Isparta.

Temiz, K. B. \& Kanlı, U. (2005). Üniversite 1. sınıf öğrencilerinin temel fizik laboratuvar araçlarını tanıma bilgileri. Milli Eğitim Dergisi, 33(168), 188-201. Erişim tarihi: 10.01.2020, http://dhgm.meb.gov.tr/yayimlar/dergiler/milli_egitim_dergisi/168/index3-temiz.htm

Wei, D., Tundong, L. \& Zhongjie, Z. (2012). Application of radio frequency identification module MFRC522 in access control system. Microcontrollers \& Embedded Systems, 12(011).

Yaren, T., Süel, V., Yeniaydın, Y., Sakacı, B. \& Kizir, S. (2014). STM32F4 kiti ile simulink tabanlı kontrol eğitimi uygulamaları geliştirme. TOK 2014 Bildiri Kitabı. 